\title{
SPECIATION IN THE EMERALD TOUCANET (AULACORHYNCHUS PRASINUS) COMPLEX
}

\author{
Fernando Puebla-Olivares, ${ }^{1,5}$ Elisa Bonaccorso, ${ }^{2}$ Alejandro Espinosa de los \\ Monteros, ${ }^{3}$ Kevin E. Omland, ${ }^{4}$ Jorge E. Llorente-Bousquets, ${ }^{1}$ \\ A. Townsend Peterson, ${ }^{2}$ and Adolfo G. Navarro-Sigüenza ${ }^{1}$ \\ ${ }^{1}$ Museo de Zoología "Alfonso L. Herrera," Facultad de Ciencias, Universidad Nacional Autónoma de México, Apartado Postal 70-399, D.F. \\ 04510, Mexico; ${ }^{2}$ Natural History Museum and Biodiversity Research Center, University of Kansas, Lawrence, Kansas 66045, USA; \\ ${ }^{3}$ Departamento de Biología Evolutiva, Instituto de Ecología, A. C., Apartado Postal 63, Xalapa, Veracruz 91000, Mexico; and \\ ${ }^{4}$ Department of Biological Sciences, University of Maryland Baltimore County, Baltimore, Maryland 21250, USA
}

\begin{abstract}
We analyzed genetic variation in the Emerald Toucanet (Aulacorhynchus prasinus), a species complex that ranges primarily along the montane forests of southern and eastern Mexico south to Bolivia. Segments of three mitochondrial DNA genes (cytochrome $b, \mathrm{ND} 2$, and ND3) were sequenced for a total of 1,159 base pairs. Using maximum parsimony, maximum likelihood, and Bayesian analysis, we found a set of seven differentiated populations that correspond to clear geographic breaks throughout the highlands of the Neotropics. These genetically distinct populations also correspond with the geographic breaks found in previous analyses of morphological data. Molecular evidence suggests species treatment for four of the Central American clades and three South American clades. Received 19 June 2006, accepted 28 January 2007.
\end{abstract}

Key words: Aulacorhynchus prasinus, biogeography, cloud forest, cytochrome $b$, Emerald Toucanet, molecular phylogeny, ND2, ND3, species limits.

\section{Especiación en el Complejo de Aulacorhynchus prasinus}

ReSUMEN.-Se analizó la variación genética de Aulacorhynchus prasinus dentro de su área de distribución geográfica en México, Centro y Sudamérica. Segmentos de tres genes mitocondriales (citocromo $b$, ND2 y ND3) fueron secuenciados para un total de 1159 pares de bases, los cuales mediante máxima parsimonia, máxima verosimilitud y análisis Bayesianos revelaron siete poblaciones diferenciadas genéticamente que se segregan de acuerdo a claros rompimientos geográficos. Las poblaciones diferenciadas corresponden, en parte, con las especies sugeridas con base en datos morfológicos en estudios previos. La evidencia molecular sugiere estatus de especie para cuatro de los clados identificados para México y Centroamérica y para tres de Sudamérica.

TOUCANS, TOUCANETS, AND araçaris (Piciformes: Ramphastidae) are among the most striking of Neotropical birds, owing to their large and brightly colored bills and bizarre plumage patterns. Such morphological variation is often associated with geographic clines or restricted to specific areas. As such, this family has been the subject of a wide array of studies dealing with their diversity (e.g., Short and Horne 2001), ecology (e.g., Riley and Smith 1992), and evolution (e.g., Haffer 1974, Hackett and Lehn 1997, Eberhard and Bermingham 2005).

The "green" toucanets in the genus Aulacorhynchus are almost completely restricted to Neotropical humid montane forests from southern and eastern Mexico south to Bolivia. Currently, they are placed in six to seven highly polytypic species (Haffer 1974, Sibley and Monroe 1990). Aulacorhynchus spp. show discrete variation in coloration and size, and several populations isolated on single mountain ranges are surprisingly distinct. However, systematic study of this genus has been slowed by the paucity of specimens throughout its range (Navarro-Sigüenza et al. 2001) and the lack of adequate series from any single site. Moreover, most species and subspecies were described in the 1800s (see Dickinson 2003) from a single or few specimens, and interrelationships among forms and their taxonomic status are often not clear (e.g., Barker and Lanyon 2000, Eberhard and Bermingham 2005).

The variation within this genus is complex, because it shows, on one hand, morphological similarity (smaller size, long and graduated tail, green overall) but, on the other hand, dramatic variation

${ }^{5}$ E-mail: fernandopuebla@hotmail.com

The Auk, Vol. 125, Number 1, pages 39-50. ISSN 0004-8038, electronic ISSN 1938-4254. (c) 2008 by The American Ornithologists' Union. All rights reserved. Please direct all requests for permission to photocopy or reproduce article content through the University of California Press's Rights and Permissions website, http://www.ucpressjournals.com/reprintInfo.asp. DOI: 10.1525/auk.2008.125.1.39 
in color patterns and bill shape (Haffer 1974, Navarro-Sigüenza et al. 2001). Vocalizations are similar among currently recognized species of Aulacorhynchus (Schwartz 1972), though most forms are allopatric and replace each other along elevational and latitudinal gradients (Gilbert 2002). Haffer (1974) presented an analysis of morphological characters and biogeography, with emphasis on the South American forms, and, more recently, Navarro-Sigüenza et al. (2001) described morphological variation of A. prasinus in Central America, for which they proposed division into four distinct species. Aulacorhynchus prasinus, as currently defined, includes 15-16 recognized subspecies, mainly distinguished by patterns of coloration of the throat and bill (Peters 1948, Winker 2000, Short and Horne 2001, Dickinson 2003).

Application of the biological species concept for the treatment of allopatric populations (e.g., Helbig et al. 2002, Remsen 2005) has led to the classic "single polytypic species" approach in the group (American Ornithologists' Union [AOU] 1998, Short and Horne 2001). However, alternative nomenclatures, which would recognize at least six species, may be more adequate for understanding the taxon from a more consistent evolutionary perspective (Wiley 1981, Navarro-Sigüenza and Peterson 2004).

Molecular characters may provide further insight into evolutionary patterns among these complex taxa for which morphology and vocalizations have not provided definite answers regarding species limits and phylogeny. Such studies are scarce for the toucans (e.g., Hackett and Lehn 1997, Weckstein 2005), and we know of no previous analyses for Aulacorhynchus. Our study also enriches knowledge of the diversification of biotas associated with montane forests and the complex array of paleoecological events, including extended isolation (García-Moreno et al. 2004). Here, we analyze the genetic variation and phylogeography of $A$. prasinus. We present sequence data from three mitochondrial genes and use the resulting phylogeny to suggest hypotheses for their evolution and to re-assess the taxonomy and species limits in the group.

\section{Methods}

Taxon sampling.-We sequenced most of the known subspecies of the Emerald Toucanet. Only two Colombian forms (A. p. lautus and $A . p$. phaeolaemus) were not included for lack of tissue samples. Our analyses, therefore, are based on tissue samples of 56 individuals that cover the area of distribution of the species (Fig. 1). For outgroup comparisons, we included two individuals of $A$.derbianus, and one individual each of A. sulcatus, A. haematopygus, and $A$. coeruleicinctis (Table 1). Tissue samples and associated voucher specimens were obtained from field work in Mexico, El Salvador (voucher specimens deposited at Museo de Zoología, Facultad de Ciencias [UNAM], and University of Kansas Natural History Museum [KUNHM]), and Venezuela (voucher specimens deposited at Colección Ornitologica Phelps [COP] and Museo de la Estación Biológica Rancho Grande [EBGR]). Additional samples were obtained from scientific collections (Table 1).

DNA isolation, amplification, and sequencing.-DNA was isolated from frozen tissue using a proteinase- $\mathrm{K}$ digestion, followed by phenol-chloroform extraction, and final ethanol precipitation (Sambrook et al. 1989). Some old or rare tissue samples were processed with the DNeasy extraction kit (Qiagen, Valencia, California), following the protocol suggested by the manufacturer. We amplified fragments of the mitochondrial genes ND2 (primers L5215-H5578; Hackett 1996), ND3 (primers L10647-H11151; Chesser 1999, Sorenson et al. 1999), and cytochrome $b$ (primers L15560-H16064; Sorenson et al. 1999) (primer position numbers are given in relation to the chicken [Gallus gallus domesticus] mitochondrial genome; Desjardins and Morais 1990). Polymerase chain reactions were performed using a three-step program of 30 cycles of $95^{\circ} \mathrm{C}$ for $1 \mathrm{~min}, 485^{\circ} \mathrm{C}$ for $2 \mathrm{~min}$, and $725^{\circ} \mathrm{C}$ for $3 \mathrm{~min}$, followed by a final extension at $725^{\circ} \mathrm{C}$ for $10 \mathrm{~min}$. Amplified products were cleaned with GenClean according to instructions and sequenced using dye-labeled terminators (BIGDYE, version 3.1; Applied Biosystems, Foster City, California). Sequencing reaction products were cleaned by gel filtration using Sephadex G50 columns (Sigma Aldrich, St. Louis, Missouri) and resolved on an ABI Prism 310 automated sequencer. Raw chromatograms were edited in CHROMAS, version 1.45 (McCarthy 1998). Final alignments were performed using CLUSTAL X (Thompson et al. 1997). All sequences have been deposited in GenBank with the following accession numbers: Cyt b: (EU285671-EU285731), ND2: (EU285732-EU285792), ND3: (EU285793-EU285850).

Population genetics descriptors.-To evaluate genetic variability within and between populations, we estimated gene flow $(\mathrm{Nm})$ and fixation indices $\left(F_{s t}\right)$ (Wright 1951, 1965). $\mathrm{Nm}$ represents an estimate of the absolute numbers of migrants exchanged between two haploid populations (Nei 1987) and is computed from pairwise $F_{s t}$ values, whereas $F_{s t}$ examines overall levels of genetic divergence among subpopulations. $F_{s t}$ has a theoretical minimum of 0 (no genetic divergence) and a theoretical maximum of 1 (fixation for alternative alleles in different subpopulations). The range 00.05 may be considered to indicate little genetic differentiation, 0.05-0.15 moderate differentiation, $0.15-0.25$ strong differentiation, and $>0.25$ very strong differentiation (Hartl and Clark 1997).

Phylogenetic reconstruction.-Congruence of phylogenetic signal among genes was tested with the incongruence length difference test (Farris et al. 1994, 1995), implemented in PAUP*, version 4.0b10 (Swofford 2000), as the partition homogeneity test; the test excluded constant characters and ran for 1,000 repetitions. Evolutionary-rate heterogeneity across lineages was tested using a likelihood ratio test (Felsenstein 1981). Significance was assessed by comparing $\Lambda=-2 \log L R$, where LR is the difference between the -ln likelihood of the tree with and without enforcing a molecular clock, with a chi-square distribution $(n-2$ degrees of freedom, where $n$ is the number of taxa). Statistical significance of departures from homogeneity in base frequencies among lineages was assessed with a chi-square test.

Phylogenetic analyses were conducted using maximum parsimony (MP), maximum likelihood (ML), and Bayesian analyses (BA). To optimize computational time, only unique haplotypes were used for estimating MP and ML trees using PAUP*; identical haplotypes were collapsed using TCS (Clement et al. 2000). Parsimony analyses were conducted in PAUP* for each gene individualy (cytochrome $b, \mathrm{ND} 2$, and ND3), as well as for the combined mitochondrial data set. We obtained MP trees through heuristic searches $(1,000$ stepwise random additions, TBR branchswapping) and estimated clade support via 1,000 bootstrap pseudoreplicates (Felsenstein 1985) with the same search options. 


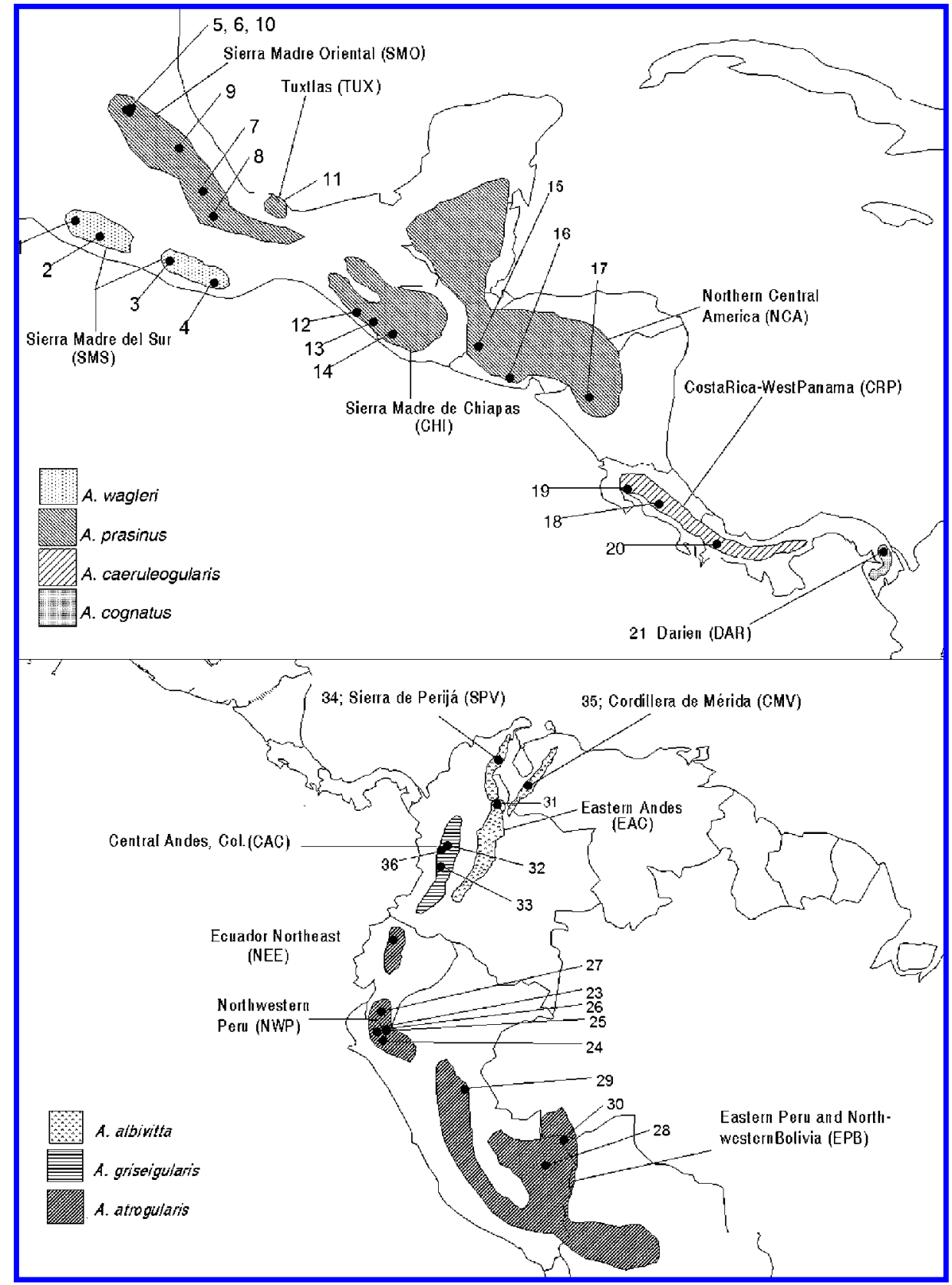

FIG. 1. Distribution of Aulacorhynchus prasinus complex in Mesoamerica (top) and South America (bottom). Black dots indicate localities where tissue samples were collected. Numbers refer to localities listed in Table 1. The stippled patterns represent the ranges of species recognized in the present study.

Prior to ML and BA analyses, best-fit models of molecular evolution for the individual genes and the combined data set were selected using MODELTEST, version 3.7 (Posada and Crandall 2001). The ML tree was obtained in PAUP* using 100 random additions, and clade support was assessed via 100 bootstrap pseudoreplicates (100 random additions each), with an initial tree generated by neighbor joining.

We performed BA in MR BAYES, version 3.1 (Ronquist and Huelsenbeck 2003), implementing a partition by gene (cytochrome $b$, ND2, and ND3) and assigning each partition its best-fit model of evolution. All parameters were unlinked between partitions, except topology and branch lengths. Analyses consisted of two runs of $2.5 \times 10^{6}$ generations and four Markov chains (one cold chain, three heated chains; temperature set to $0.205^{\circ} \mathrm{C}$ ), with trees sampled every 1,000 generations. From the 2,500 resulting trees, the first 500 were discarded as "burn-in," and the rest were used to calculate posterior probabilities in a $50 \%$ majority-rule consensus tree. Stationarity was confirmed by plotting - $\ln \mathrm{L}$ per generation. 
TABLE 1. Collection localities and museum catalogue number for specimens from which tissue samples were used in the genetic analysis. See Figure 1 for localities.

\begin{tabular}{|c|c|c|c|c|c|}
\hline $\begin{array}{l}\text { Locality } \\
\text { no. }\end{array}$ & Haplotype & Locality & Subspecies & $\begin{array}{l}\text { Museum and } \\
\text { catalogue number }\end{array}$ & $\begin{array}{l}\text { Abbreviation } \\
\text { in Fig. } 2\end{array}$ \\
\hline 1 & A & Mexico, Guerrero, Carrizal de Bravo & wagleri & MZFC CAON 78 & MexGuerrero1 \\
\hline 2 & A & Mexico, Guerrero, Sierra de Petatlán & wagleri & MZFC CAON147, 149 & MexGuerrero2-3 \\
\hline 3 & B & Mexico, Oaxaca, Putla, Sta Ana del Progreso & wagleri & MZFC OMVP 697, 705, 708 & MexSouthwestOax1-3 \\
\hline 4 & C, D & Mexico, Oaxaca, Miahuatlán, Pluma Hidalgo & wagleri & MZFCONA 205-206 & MexSoutheastOax1-2 \\
\hline 5 & $\mathrm{E}$ & Mexico, Hidalgo, Chalpuhuacan, Arroyo Blanco & prasinus & MZFCBMM 898-899 & MexHidalgo1-2 \\
\hline 6 & $\mathrm{E}$ & Mexico, Hidalgo, Pisaflores, El Coyol & prasinus & MZFC H-SLP139 & MexHidalgo3 \\
\hline 7 & $\mathrm{E}$ & Mexico, Veracruz, Cordoba, Naranjal & prasinus & MZFC NAR 29 & MexVeracruz \\
\hline 8 & $\mathrm{E}$ & Mexico, Oaxaca, Teotitlán, San Martin Caballero & prasinus & MZFC OMVP 1071 & MexNorthOaxaca \\
\hline 9 & $\mathrm{E}$ & Mexico, Puebla, Jonotla & prasinus & MZFC PUE 154 & MexPuebla \\
\hline 10 & $\mathrm{E}$ & Mexico, Querétaro, Landa de Matamoros & prasinus & MZFC QRO 324 & MexQuerétaro \\
\hline 11 & $\mathrm{~F}$ & $\begin{array}{l}\text { Mexico, Veracruz, Sontecomapan, Sierra Sta } \\
\text { Marta }\end{array}$ & warneri & MZFCF TUXO1-03 & MexTux1-3 \\
\hline 12 & G & Mexico, Chiapas, El Triunfo & chiapensis & INECOL 01 & MexChiapas1 \\
\hline 13 & G & Mexico, Unión Juárez, Volcán Tacaná & chiapensis & MZFC BMM 803 & MexChiapas2 \\
\hline 14 & G & Guatemala, Quetzaltenango, Sta Maria de Jesús & chiapensis & DHB4450 & GuatQuetzal \\
\hline 15 & $\mathrm{H}$ & El Salvador, Cacahuatique & stenorhabdus & MZFC EAGT 38 & ElSalNorth \\
\hline 16 & 1 & El Salvador, Volcán San Miguel & volcanius & MZFCPUE01-02 & EISalVolSanMig1-2 \\
\hline 17 & J & Nicaragua, Matagalpa & virescens & DAB1273, 13140, 1367,1368 & Nicaragua1-4 \\
\hline 18 & $\mathrm{~K}$ & Costa Rica, Cartago, Muñeco & maxillaris & UCR1211 & CostaRica1 \\
\hline 19 & K & Costa Rica, Monteverde, Puntarenas & maxillaris & UCR3965, UCRnone & CostaRica2-3 \\
\hline 20 & $\mathrm{~L}$ & Panamá, Chiriquí, Gualaca, Lago Fortuna & caeruleogularis & LSUMZ-26464, 26403 & PanamaWest1-2 \\
\hline 21 & M & Panamá, Darién, Cerro Pirre & cognatus & LSUMZ-1373 & Darien \\
\hline 22 & $\mathrm{~N}$ & Ecuador, Napo, El Chaco, Mirador & albivitta & ANSP4837, 4799 & Ecuador, Northeast1-2 \\
\hline 23 & $\mathrm{O}$ & Peru, Cajamarca, Machete on Sapalache & cyanolaemus & LSUMZ-213 & PeruWest1 \\
\hline 24 & $\mathrm{O}$ & $\begin{array}{l}\text { Peru, Cajamarca, Quebrada Las Palmas, } \\
\text { Chontalli }\end{array}$ & cyanolaemus & LSUMZ-32663, 32676, 32829 & PeruWest2-4 \\
\hline 25 & $\mathrm{O}$ & Peru, Cajamarca, San José de Lourdes & cyanolaemus & LSUMZ-33050, 33052 & PeruWest5-6 \\
\hline 26 & $\mathrm{O}$ & $\begin{array}{l}\text { Peru, Cajamarca, Cordillera del Cóndor, } \\
\text { Picorana }\end{array}$ & cyanolaemus & LSUMZ-33837, 33865 & PeruWest7-8 \\
\hline 27 & $\mathrm{O}$ & Ecuador, Loja & cyanolaemus & ZMUC 115022 & EcuadorSouthwest \\
\hline 28 & $\mathrm{P}$ & $\begin{array}{l}\text { Peru, Madre de Dios, Colpa Guacamayos, Río } \\
\text { Tambopata }\end{array}$ & atrogularis & LSUMZ-21201 & PeruSoutheast \\
\hline 29 & $\mathrm{P}$ & Peru, Ucayali, Río Shesha, Pucalpa & atrogularis & LSUMZ-10742 & PeruNortheast \\
\hline 30 & $\mathrm{P}$ & Bolivia, Pando, Nicolaz Suárez, Mucden & dimidiatus & LSUMZ-9661 & Bolivia, Northwest \\
\hline 31 & V & $\begin{array}{l}\text { Colombia, Carrizal, Cucutilla, Norte de } \\
\text { Santander }\end{array}$ & albivitta & IAvH-CT 1752 & ColEasternAndes \\
\hline 32 & Q & Colombia, Caldas, El Laurel, Aranzazu & griseigularis & IAvH-CT 1696 & ColCentralAndes 1 \\
\hline 33 & $\mathrm{~S}$ & Colombia, Valle del Cauca, Chicoral, La Cumbre & griseigularis & IAvH-CT 2611 & ColCentralAndes2 \\
\hline 34 & $\mathrm{~T}$ & $\begin{array}{l}\text { Venezuela, Zulia, Sierra de las Lajas, Serranía de } \\
\text { Perijá }\end{array}$ & albivitta & COP81127, 81128 & VenSierraPerijá1, 2 \\
\hline 34 & $U$ & $\begin{array}{l}\text { Venezuela, Zulia, Sierra de las Lajas, Serranía de } \\
\text { Perijá }\end{array}$ & albivitta & COP81129 & VenSierraPerijá3 \\
\hline 35 & V & Venezuela, Mérida, La Mucuy & albivitta & KUNHM EB12 & VenCordilleraMérida \\
\hline \multirow[t]{5}{*}{36} & $\mathrm{R}$ & Colombia, Risaralda, Pueblo Rico, La Cumbre & griseigularis & $\mathrm{IAvH}-\mathrm{CT} 4003$ & ColCentralAndes3 \\
\hline & & Venezuela, Aragua, Rancho Grande & A. sulcatus & EBRG 12237 & Outgroup \\
\hline & & Ecuador, El Oro, Machalilla, Cerro San Sebastián & A. haematopygus & ANSP 2912 & Outgroup \\
\hline & & Peru, Pasco, Santa Cruz, 9 km SSE Oxapampa & A. coeruleicinctis & LSU 1616 & Outgroup \\
\hline & & Guyana & A. derbianus & ANSP3964, 4080 & Outgroup \\
\hline
\end{tabular}

Acronyms: ANSP = Academy of Natural Sciences, Philadelphia; EBGR = Museo Estación Biológica de Rancho Grande, Venezuela; KUNHM = Natural History Museum, University of Kansas; COP = Colección Ornitológica Phelps, Caracas, Venezuela; LSUMZ = Museum of Natural Science, Louisiana State University; MZFC = Museo de Zoología, Facultad de Ciencias, Universidad Nacional Autónoma de México; UCR = Universidad de Costa Rica; ZMUC = Zoological Museum of the University of Copenhagen; $\mathrm{DAB}$ and $\mathrm{DHB}=$ Barrick Museum, University of Nevada, Las Vegas; IAvH = Instituto Alexander von Humboldt, Colombia; and INECOL = Instituto de Ecología, Jalapa, Veracruz, México. 


\section{Results}

Genetic distances among species of Aulacorhynchus used as outgroups varied $6.7-11.4 \%$, whereas ingroup populations were $10.1-12.7 \%$ divergent from outgroups (Table 2). For the complete mitochondrial data set, MODELTEST selected the GTR $+\Gamma$ model (for cytochrome $b$, the TIM $+\Gamma$; for ND2, the TVM $+\mathrm{I}$; and for ND3, the HKY $+\Gamma$ model). Our final data matrix included 61 sequences (1,159 base pairs [bp]), of which 26 represented unique haplotypes (22 haplotypes for Emerald Toucanet and 4 from outgroups; Table 2). Informative sites were distributed among genes as follows: 92 for cytochrome $b$ (444 bp), 64 for ND2 (363 bp), and 55 for ND3 (352 bp).

Maximum-parsimony analyses for the three genes produced trees that were largely congruent; the few nodes that differed between genes were generally not well supported (bootstrap values $<50 \%)$. Also, the results of the partition homogeneity test were not significant $(P=0.95)$. Hence, because we found no sign of phylogenetic incongruence, we were confident of the appropriateness of conducting further analyses using a combined data set. We found no evidence of heterogeneity in base frequencies among lineages for the combined data set (chi-square test, $P>0.05$ ), and empirical base frequencies were relatively similar to those estimated by MODELTEST under the GTR $+\Gamma$ model.

The combined data set produced two most parsimonious trees (510 steps; consistency index $[\mathrm{CI}]=0.6824$, retention index $[\mathrm{RI}]=$ 0.8318 , rescaled consistency index $[R C]=0.5676$ ), which differed only in the position of one haplotype in a clade that groups all samples from the Sierra Madre Oriental (not shown). Maximumlikelihood analysis recovered a single tree $(-\ln L=4,123.1724$; GTR $+\Gamma$ model; base frequencies: $\mathrm{A}=0.277, \mathrm{C}=0.3744, \mathrm{G}=0.1071$, $\mathrm{T}=0.2415$; substitutions: $\mathrm{A}-\mathrm{C}=0.5377, \mathrm{~A}-\mathrm{G}=14.0171, \mathrm{~A}-\mathrm{T}=$ $0.7333, \mathrm{C}-\mathrm{G}=1.8386, \mathrm{C}-\mathrm{T}=9.8144, \mathrm{G}-\mathrm{T}=1$; shape parameter $=$ 0.2229 ), the topology of which was highly congruent with those of the MP and BA trees. Therefore, we present the BA tree, indicating the level of node support recovered by BA, ML, and MP analyses (Fig. 2). Finally, given that the LR test detected significant rate heterogeneity among lineages (molecular clock rejected; $\chi^{2}=$ 37.65, $P=0.05)$, divergence times were not calculated among clades.

Our tree (Fig. 2) shows A. prasinus populations forming a monophyletic group. Ingroup samples were divided into two main clades with high bootstrap support: a Mesoamerican clade of haplotypes distributed in Mexico and Central America, and a second clade with haplotypes distributed in South America; between these clades, the average genetic distance was $7.03 \%$ (Table 2), $F_{s t}=0.57$, and $N m=0.18$ (Table 3).

The South American clade was divided into two sister groups. The first group (Venezuelan group [VEN]) includes samples from Sierra de Perijá ( $\mathrm{T}$ and $\mathrm{U}$ haplotypes) and Cordillera de Mérida in Venezuela (haplotype V), and a sample from the eastern Andes of Colombia (EAC; also haplotype V). The second group includes samples from the eastern Andes of Peru and northwestern Bolivia (EPB; P haplotype), the Andes of northeastern Ecuador (NEE; O haplotype) and northwestern Peru (NWP; O haplotype), and the Central Andes of Colombia (CAC; Q, S, and R haplotypes). Average genetic distance among these groups was $5.16 \%$, which indicates strong genetic differentiation and null gene flow (Tables 2 and 3).
The genetic distance among the samples from Sierra de Perijá and Cordillera de Mérida was $0.4 \%$. Within the second group, the clade from the Central Andes of Colombia was sister to the rest of the Andean samples, and among them the average genetic distance was $1.57 \%$ (Table 2 ).

In Mesoamerica, we recovered four main clades. The first includes the $M$ haplotype from Darien, eastern Panama (DAR). This clade was sister to the other Mesoamerican populations, with an average genetic divergence of $6.13 \%$ between them (Table 2 ), with $F_{s t}=0.52$ and $N m=0.23$ (Table 3). The second clade includes samples from Chiriquí and Veraguas in western Panama (L haplotype) and from the Cordillera Volcánica of Costa Rica (CRP; K haplotype). Relatively low levels of mtDNA divergence (0.09\%; Table 2) were observed between these two regions, which suggests a lack of isolation between the two. This Costa RicaPanama clade is sister to the northern Central America and Mexican populations, with an average genetic divergence of $5.36 \%$, which indicates strong genetic differentiation and null gene flow (Tables 2 and 3).

The northern Central American and Mexican populations were divided into two main clades. The first includes samples from El Salvador ( $\mathrm{H}$ and I haplotypes) and Nicaragua (J haplotype) (here called the northern Central America population [NCA]), and southern and eastern Mexico (Tuxtlas [TUX], F haplotype; Sierra Madre Oriental [SMO], E haplotype; and Sierra Madre del Sur de Chiapas [CHI], G haplotype). The last clade includes samples from the Sierra Madre del Sur (SMS; Guerrero and southern Oaxaca; A, B, C, and D haplotypes), this being the sister group of the rest of the Mexican populations, with an average genetic divergence of $3.68 \%$ from them, strong genetic differentiation, and null gene flow. An average genetic divergence of only $1.0 \%$ was found within the Sierra Madre del Sur clade (Tables 2 and 3).

In sum, we identified clear genetic subgroups within A. prasinus, which are distributed in a long, slender chain through the montane Neotropics. Genetic differentiation $\left(F_{s t}\right)$ among adjacent pairs of these subgroups, and among sister subgroups as defined by the phylogenetic results, were very high; they varied between 0.49 and 1.00 (Table 3). This result indicates strong genetic divergence among populations (Hartl and Clark 1997), as well as low or null gene flow among them, which suggests a long history of isolation and high genetic differentiation (Table 3).

\section{Discussion}

Phylogeny.-Previous analyses have stressed the dramatic morphological variation among isolated populations of the Emerald Toucanet (A. "prasinus" sensu lato) throughout its range (Peters 1948, Wetmore 1968, Haffer 1974, O’Neill and Gardner 1974, Winker 2000). Careful analyses of morphology and coloration have also led to the proposal that the group is, in fact, composed of several species (Navarro-Sigüenza et al. 2001). However, given that no genetic data were available at that time, that proposal was largely ignored (Remsen 2005).

First, we consider the well-supported monophyly of the populations included in A. "prasinus" (e.g., AOU 1998), in spite of its considerable morphological variation (Haffer 1974, Short and Horne 2001, Gilbert 2002). Ongoing phylogenetic analyses that 


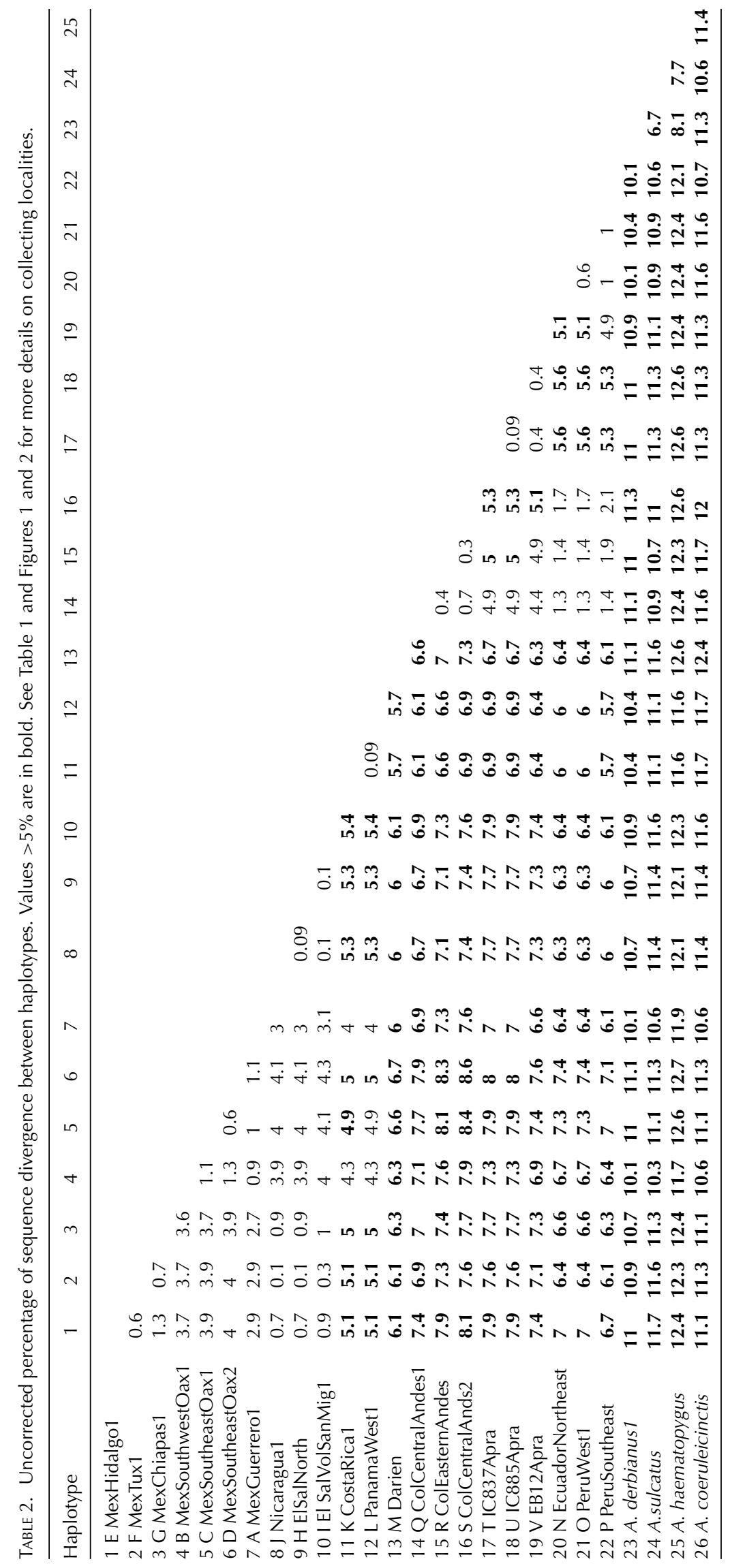




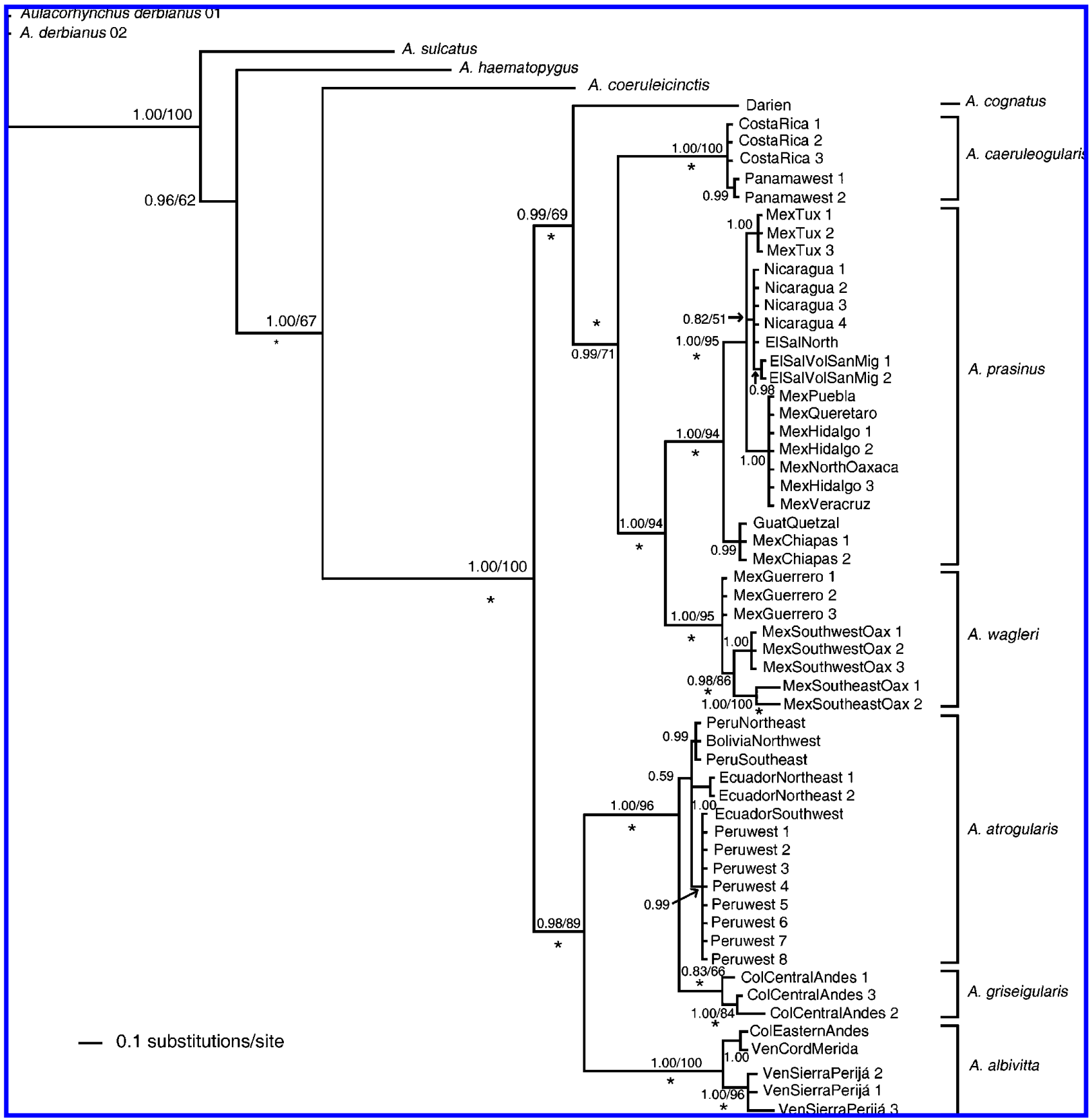

FIG. 2. Bayesian $50 \%$ majority-rule consensus tree that resulted from the analysis of cytochrome $b$, ND2, and ND3 combined. Numbers over nodes indicate posterior probability values and maximum-likelihood bootstrap support; numbers below nodes show parsimony bootstrap support; asterisk indicates maximum-parsimony bootstrap support $>70 \%$; terminal nodes showing only posterior probability values represent identical haplotypes. Putative phylogenetic species are labeled along the right margin. See Table 1 for current subspecific names assigned to haplotypes in the phylogeny.

include the full set of Aulacorhynchus species are in preparation (E. Bonaccorso unpubl. data).

Second, concordant with the morphological variation within A. "prasinus" (Navarro-Sigüenza et al. 2001), we found deep divergence values among its subclades, comparable to levels of sequence divergence between other species of Aulacorhynchus (e.g.,
A. derbianus vs. A. sulcatus 6.7\%; A. sulcatus vs. A. haematopygus 7.7\%; Table 1). Our study shows high levels of genetic variation among populations of this complex.

The MP, ML, and Bayesian analyses recovered the same major clades and agreed on patterns of relationships among them. The phylogenetic reconstruction showed seven well-differentiated 
TABLE 3. Average genetic distance, parameters of genetic differentiation $\left(F_{s t}\right)$, and gene flow $(\mathrm{Nm})$ among sister clades defined by phylogenetic relationships and between some geographically close populations.

\begin{tabular}{|c|c|c|c|c|}
\hline & $\begin{array}{c}\text { Average genetic } \\
\text { distance }(\%)\end{array}$ & $F_{\mathrm{ST}}$ & $P$ & $\mathrm{Nm}$ \\
\hline $\begin{array}{l}\text { (Meso America)-(South } \\
\text { America) }\end{array}$ & 7.02 & 0.57 & 0.000 & 0.18 \\
\hline $\begin{array}{l}\text { (EPB-NEE-NWP-CAC) and } \\
\text { VEN }\end{array}$ & 5.16 & 0.91 & 0.000 & 0.02 \\
\hline (EPB-NEE-NWP) and CAC & 1.57 & 0.59 & 0.009 & 0.17 \\
\hline (NEE-NWP) and EPB & 1 & 0.86 & 0.003 & 0.04 \\
\hline (NWP) and (NEE) & 0.6 & 1 & 0.022 & 0 \\
\hline $\begin{array}{l}\text { (NCA-SMO-TUX-CHI-SMS- } \\
\text { CRP) and (DAR) }\end{array}$ & 6.13 & 0.52 & 0.000 & 0.23 \\
\hline $\begin{array}{l}\text { (NCA-SMO-TUX-CHI-SMS) } \\
\text { and (CRP) }\end{array}$ & 5.36 & 0.82 & 0.000 & 0.05 \\
\hline $\begin{array}{l}\text { (NCA-SMO-TUX-CHI) and } \\
(\text { SMS) }\end{array}$ & 3.68 & 0.80 & 0.000 & 0.06 \\
\hline (NCA-SMO-TUX) and (CHI) & 0.96 & 0.76 & 0.000 & 0.08 \\
\hline
\end{tabular}

Abbreviations refer to groups of samples included in clades in the phylogeny; see text, Table 1, and Figure 1: VEN = Venezuelan group, EPB = Eastern Andes of Peru and northwestern Bolivia, NEE $=$ Andes of northeastern Ecuador, NWP $=$ northwestern Peru, $\mathrm{CAC}=$ Central Andes of Colombia, DAR $=$ Darien, $\mathrm{CRP}=$ Costa Rica-Western Panama, NCA $=$ northern Central America, TUX $=$ Tuxtlas, $\mathrm{SMO}=$ Sierra Madre Oriental, $\mathrm{CHI}=$ Sierra Madre del Sur de Chiapas, and SMS $=$ Sierra Madre del Sur.

clades in a hierarchical pattern of relationships. These clades agree with well-defined biogeographic limits across the distribution of the complex; they also agree with limits based on morphological evidence and with patterns for other bird species with similar distributions, at least in Mexico and Central America (e.g., GarcíaMoreno et al. 2004, Solórzano et al. 2004).

The phylogeny recovered a deep separation between the populations of South America and those of Central America and Mexico (Mesoamerica). Such deep splits have been observed for other bird complexes with similar distributions (e.g., Eberhard and Bermingham 2004, 2005). Curiously, this separation does not coincide with the lowland break in central Panama, but occurs in the complex Darien region; our genetic data suggest deep genetic differentiation and no gene flow among northern and southern clades. This is contrary to Haffer (1967), who suggested that the avifauna of Darien was related to that of the Andes, from which it is derived (e.g., Calliphlox mitchellii). The Darien populations are isolated by $\sim 200 \mathrm{~km}$ of lowlands separating them from the highlands of northwestern Colombia (Porter 1973, Robbins et al. 1985). Also, the montane areas of Darien, western Panama, and northwestern Colombia have different geological histories (Bartlett and Barghoorn 1973), which may have influenced the deep split we observed for the Darien populations, as well as for other taxa discussed by Robbins et al. (1985).

On the other hand, the Costa Rica-Western Panama clade includes the forms recognized as $A$. prasinus caeruleogularis of the regions of Chiriquí and Veraguas in western Panama, and $A$. $p$. maxillaris of Costa Rica (Peters 1948, Haffer 1974). This clade also shows deep genetic differentiation (5.36\%) compared with its sister group (northern Central America and Mexico), isolated by the lowlands of Lake Nicaragua, which impedes gene flow among populations of other montane bird taxa (e.g., Pharomachrus moccinno; Solórzano et al. 2004). Very low levels of genetic differentiation (0.09) were observed within this clade.

The Sierra Madre del Sur clade in southeastern Mexico (currently recognized as $A$. p. wagleri) shows deep genetic differentiation (3.6\%) from its sister group (eastern Mexico and northern Central America). Surprisingly, a nontrivial average genetic distance of $1.0 \%$ was observed between the Guerrero and Oaxaca populations of this clade, despite being separated only by the Río Verde drainage (Ferrusquía 1998); similar differentiation has been reported for hummingbirds in the genus Eupherusa (Hernández-Baños et al. 1995) and bush-tanagers in the genus Chlorospingus (García-Moreno et al. 2004). Further analyses are necessary to better understand the biogeographic and evolutionary implications of these differences.

Sister to the populations from Sierra Madre del Sur is a clade that includes the populations from eastern Mexico and northern Central America. A basal split separates populations of the Sierra Madre de Chiapas and Guatemala (current A. p. chiapensis; Peters 1948), with an average genetic differentiation of $0.96 \%$ compared with the rest of this clade. This population is isolated from the remaining Central American populations by the Rio Motagua Valley in Guatemala. Curiously, though, other Central American populations nestle within the Mexican members of this clade. More generally, minor subclades correspond to the populations of (1) the Tuxlas massif, (2) Nicaragua and El Salvador, and (3) eastern Mexico, but levels of differentiation are low.

Differentiation within the South American clade provides a view of the complexities of speciation in the region. The first split off this broad lineage is the one that includes populations of the Sierra de Perijá, Cordillera de Mérida, and the Eastern Andes of Colombia; this clade differs genetically by $5.16 \%$ from the remaining South American populations. An average genetic distance of $0.4 \%$ was observed inside this clade, an order of magnitude lower. This isolated Venezuelan and eastern Colombian clade (form A. $p$. albivitta) is, thus, quite distinct in molecular characters as well as phenotypic features (Peters 1948, Haffer 1974).

The sister clade to the A. p. albivitta lineage includes populations of the Central Andes of Colombia, as well as of Ecuador, Peru, and Bolivia. The Colombian populations (form A.p.griseigularis), a well-supported clade, are distributed along the Central Andes of Colombia and differ by an average genetic distance of $1.57 \%$.

Populations from Ecuador, Peru, and Bolivia belong to a poorly supported clade with relationships that are not resolved. This group includes populations assigned to subspecies cyanolaemus, atrogularis, and dimidiatus (Haffer 1974, Navarro-Sigüenza et al. 2001, Short and Horne 2001). Although low levels of differentiation between some populations allow perception of some geographic structuring, our results suggest that the intergradation of morphological traits among those "subspecies" (Haffer 1974) may reflect gene flow or recent connection among them.

A full picture of divergence patterns among all $A$. prasinus populations was not possible because of a lack of samples from the Western Andes (form A. p. phaeolaemus) and the Sierra de Santa Marta (A. p. lautus) in Colombia. These regions are 
examples of extreme geomorphological complexity, formed by several mountain ranges of different geological origins (Kattan et al. 2004). Future sampling from these regions will provide a more complete view of the biogeographic history and speciation of A. prasinus and other taxa in South America.

Biogeographic history of Aulacorhynchus "prasinus."-Given the phylogenetic relationships just discussed, we can reconstruct a general hypothesis of the historical biogeography of the populations of A. prasinus. Emerald Toucanets have been considered a group whose distribution and differentiation fit nicely into the "refugia" hypothesis of diversification in the Neotropics as a result of Pleistocene climatic fluctuations (Haffer 1974), via cycles of range contraction and expansion resulting in fragmentation and isolation of populations, with subsequent speciation (Toledo 1982, Llorente 1984, Whitmore and Prance 1987, Graham 1998).

Although genetic data for toucanets from the northernmost areas in Colombia are not yet available, similar patterns of a basal separation of Mesoamerican and South American populations were also observed in Amazona ochrocephala (Eberhard and Bermingham 2004). This old divergence appears to have been followed in South America by range expansion southward through the Andes, with basal populations in the isolated ranges of the northern Andes. The low levels of genetic differentiation observed among populations in Ecuador, Peru, and Bolivia suggest that the events that caused their divergence are more recent, which agrees with Pleistocene climatic fluctuations, even though direct evidence is limited. Similar biogeographic patterns have been found in the Pionopsitta and Pteroglossus complexes (Eberhard and Bermingham 2005). Nevertheless, other studies indicate additional factors, such as the importance of the emergence of the Andes (Kattan et al. 2004), riverine barriers (García-Moreno and Fjeldså 2000, Franke et al. 2005), or even the linearity of the Andes, which results in elongated geographical ranges of taxa that reduces the potential contact and gene flow of parapatric forms (Graves 1982, Remsen 1984).

In Central America, short genetic distances among populations and relationships between Mesoamerican and South American lineages suggest that "Emerald Toucanet" ancestors have been present in Central America for a long time, with a northward expansion of populations from southern Central America. Both the short internodes and the short terminal branch lengths of the northern Central American and Mexican populations suggest that diversification in the area was relatively quick and more recent. That is to say, an ancestral population could have been divided by vicariant events via fragmentation of the cloud forests as the climates changed. Similar vicariant mechanisms have been suggested in studies of other habitat-restricted taxa, including amphibians (Campbell 1999), mammals (Sullivan et al. 1997, 2000; L. León-Paniagua et al. unpubl. data), birds (García-Moreno et al. 2004, 2006), and beetles (Liebherr 1991, Marshall and Liebherr 2000). Dispersal, nonetheless, cannot be ruled out as an alternative explanation for this biogeographic pattern.

Taxonomic implications.-According to the morphological evidence available (Navarro-Sigüenza et al. 2001, Short and Horne 2001), paired with the molecular data presented here that suggest clear differentiation and lack of gene flow between clades, a full re-evaluation of the taxonomy of the forms included in A. "prasinus" (sensu AOU 1998) is needed. Deep divergences among the groups of populations discussed above clearly reflect long periods of significant genetic isolation (Burns 1997, Johnson and Sorenson 1999, Omland et al. 1999; Table 2).

All clades under discussion can be identified easily by diagnostic morphological attributes, including size and color patterns related to beak or plumage characteristics (Navarro-Sigüenza et al. 2001, contra Short and Horne 2001). These characters are important in social and reproductive behavior in the Ramphastidae (Skutch 1967, Haffer 1974); therefore, they could facilitate reproductive isolation in cases where populations came into contact. As a result, the clades that we have identified likely represent species entities recognizable under the biological, evolutionary, and phylogenetic concepts (Cracraft 1983, McKitrick and Zink 1988, Mayr 2000, Navarro-Sigüenza and Peterson 2004). Thus, we consider that sufficient morphological and genetic evidence (Helbig et al. 2002) is available now to re-evaluate the taxonomic status of the group, and we suggest that four species in Mesoamerica and three in South America be recognized. The Mesoamerican taxa largely correspond to those suggested by Navarro-Sigüenza et al. (2001); English names follow Ridgway (1914) and Hilty (2003):

(1) Aulacorhynchus cognatus (Nelson 1912). Goldman's Bluethroated Toucanet. Endemic to the isolated mountains in the Darien of eastern Panama (Cerro Pirre and Cerro Tacarcuna; Robbins et al. 1985, Hilty and Brown 1986). Although this form has been considered morphologically very similar to $A$. caeruleogularis, the base of the culmen is black and individuals are somewhat smaller.

(2) Aulacorhynchus caeruleogularis (Gould 1854). Bluethroated Toucanet. This species is endemic to the mountains of Costa Rica and western Panama and is well differentiated from the other Mesoamerican species. It includes the forms caeruleogularis and maxillaris (Peters 1948), among which low levels of mtDNA divergence were observed.

(3) Aulacorhynchus wagleri (Sturm and Sturm 1841). Wagler's Toucanet. Endemic to the Sierra Madre del Sur of Guerrero and southern Oaxaca in Mexico. This species shows strong genetic differentiation from other Mesoamerican species and is characterized mainly by black at the base of the beak.

(4) Aulacorhynchus prasinus (Gould 1833). Emerald Toucanet. Inhabits cloud forest from northeastern Mexico south to Nicaragua and includes warneri from the Tuxtlas; chiapensis from the Pacific slopes of southern Chiapas and southwestern Guatemala; virescens from northern Guatemala, Belize, Honduras, and Nicaragua; stenorhabdus from northern El Salvador; and volcanius from the San Miguel Volcano of El Salvador (Peters 1948).

(5) Aulacorhynchus albivitta (Boissonneau 1840). Whitethroated Toucanet. Ranges along the Andes of northern South America from Venezuela and eastern Colombia. This form is widespread along the northern Andes, and no variation has been described among its populations (Dickinson 2003).

(6) Aulacorhynchus griseigularis Chapman 1915. Greythroated Toucanet. Endemic to the central and western Andes of Colombia. We ascribe three Colombian samples to this taxon on the basis of distributional data presented by Haffer (1974) and the 
deep morphological (Navarro-Sigüenza et al. 2001) and molecular differences exhibited.

(7) Aulacorhynchus atrogularis (Sturm and Sturm 1841). Black-throated Toucanet. Ranges along the eastern slopes of the Andes of Peru and Bolivia and includes forms cyanolaemus (Ecuador and Peru), dimidiatus (Bolivia), and nominate atrogularis (O’Neill and Gardner 1974, Navarro-Sigüenza et al. 2001). Although we detected relatively high values of genetic divergence between some of the populations within this clade, our data support the hypothesis of ample intergradation among forms. More sampling is necessary to elucidate the status of these populations, for each of which species status has been suggested (Gilbert 2002).

Many challenges remain for a complete understanding of the evolution and diversification of Aulacorhynchus in the Neotropics. Moreover, for South American populations we have analyzed only a minor proportion of the diversity in this complex. Our results suggest the importance of history along with ecological factors in the process of speciation of A. prasinus. This study, together with others that address evolution in similarly distributed taxa (e.g., García-Moreno et al. 2004, 2006; Pérez-Emán 2005; Dingle et al. 2006) contribute to a new understanding of the complexities of the evolution in the rich Neotropical montane avifauna.

\section{ACKNOWLeDgments}

Thanks to L. León, A. Gordillo, J. J. Morrone, and two anonymous reviewers who made valuable comments on previous versions of the manuscript. We thank the curators of the following collections, and other individuals, for access to tissue samples: Museo Estación Biológica Rancho Grande, Venezuela (EBGR); J. D. Palacio and C. Villafane, Instituto Alexander von Humboldt, Colombia (IAcH); Academy of Natural Sciences of Philadelphia (ANSP); Museum of Natural Science, Louisiana State University (LSUMZ); Museo de Zoología, Facultad de Ciencias, Universidad Nacional Autónoma de México (MZFC); M. Lentino and I. Carreño, Colección Ornitológica Phelps (COP), Caracas; Universidad de Costa Rica (UCR); Zoological Museum of the University of Copenhagen (ZMUC); J. Klicka, Barrick Museum, University of Nevada, Las Vegas (UNLV); University of California Berkeley; and F. González-García, Instituto Nacional de Ecología Xalapa, Veracruz, México. Collecting permits were granted by Instituto Nacional de Ecología (SEMARNAT, México), Ministerio del Medio Ambiente (El Salvador), and Ministerio del Ambiente (Venezuela). We appreciate assistance in obtaining samples in the field from O. Komar, R. Gutiérrez, C. Almazán, L. A. Sánchez-González, E. Figueroa, B. Hernández, O. Rojas, S. López, G. García-Deras, E. García-Trejo, J. Pérez-Emán, M. Lentino, and I. Carreño. We especially thank L. Márquez and B. Hernández for help in the laboratory at UNAM (Museo de Zoología and Instituto de Biología) and L. F. García (Laboratorio de Genética, Departamento de Biología Universidad Nacional de Colombia) and J. M. Guayasamin for making the molecular work possible. Funding for developing various stages of the project was obtained from the SEMARNAT-CONACyT Sectorial Funds (C01-0265), CONACyT R-27961 Research Grant; CONACyT and DGEP granted a doctoral fellowship to F.P.-O.; and National Science Foundation granted a Dissertation Improvement Grant (DEB-0508910) to E.B.

\section{Literature Cited}

American Ornithologists' Union. 1998. Check-list of North American Birds, 7th ed. American Ornithologists' Union, Washington, D.C.

BARKER, F. K., AND S. M. LANYON. 2000. The impact of parsimony weighting schemes on inferred relationships among toucans and Neotropical barbets (Aves: Piciformes). Molecular Phylogenetics and Evolution 15:215-234.

Bartlett, A. S., And E. S. Barghoorn. 1973. Phytogeographic history of the Isthmus of Panama during the past 12,000 years (A history of vegetation, climate, and sea-level change). Pages 203-299 in Vegetation and Vegetational History of Northern Latin America (A. Graham, Ed.). Elsevier, New York.

BURNS, K. J. 1997. Molecular systematics of tanagers (Thraupinae): Evolution and biogeography of a diverse radiation of Neotropical birds. Molecular Phvlogenetics and Evolution 8:334-348.

Campbell, J. A. 1999. Distribution patterns of amphibians in Middle America. Pages 111-210 in Patterns of Distribution of Amphibians: A Global Perspective (W. E. Duellman, Ed.). Johns Hopkins University Press, Baltimore, Maryland.

Chesser, R. T. 1999. Molecular systematics of the rhinocryptid genus Pteroptochos. Condor 101:439-446.

Clement, M., D. Posada, and K. A. Crandall. 2000. TCS: A computer program to estimate gene genealogies. Molecular Ecology 9:1657-1659.

CRACRAFT, J. 1983. Species concepts and speciation analysis. Pages 159-187 in Current Ornithology, vol. 1 (R. F. Johnston, Ed.). Plenum Press, New York.

Desjardins, P., AND R. Morais. 1990. Sequence and gene organization of the chicken mitochondrial genome: A novel gene order in higher vertebrates. Journal of Molecular Biology 212:599-634.

Dickinson, E. C., Ed. 2003. The Howard and Moore Complete Checklist of the Birds of the World, 3rd ed. Princeton University Press, Princeton, New Jersey.

Dingle, C., I. J. Lovette, C. Canaday, and T. B. Smith. 2006. Elevational zonation and the phylogenetic relationships of the Henicorhina wood-wrens. Auk 123:119-134.

Eberhard, J. R., And E. Bermingham. 2004. Phylogeny and biogeography of the Amazona ochrocephala (Aves: Psittacidae) complex. Auk 121:318-332.

Eberhard, J. R., And E. Bermingham. 2005. Phylogeny and comparative biogeography of Pionopsitta parrots and Pteroglossus toucans. Molecular Phylogenetics and Evolution 36:288-304.

Farris, J. S., M. Källersjö, A. G. Kluge, ANd C. Bult. 1994. Testing significance of incongruence. Cladistics 10:315-319.

Farris, J. S., M. Källersjö, A. G. Kluge, ANd C. Bult. 1995. Constructing a significance test for incongruence. Systematic Biology 44:570-572.

Felsenstein, J. 1981. Evolutionary trees from DNA sequences: A maximum likelihood approach. Iournal of Molecular Evolution 17:368-376. 
Felsenstein, J. 1985. Confidence limits in phylogenies: An approach using the bootstrap. Evolution 39:783-791.

Ferrusquía, V. I. 1998. Geología de México: Una sinopsis. Pages 3-108 in Diversidad Biológica de México: Orígenes y Distribución (T. P. Ramamoorthy, R. Bye, A. Lot, and J. Fa, Eds.). Universidad Nacional Autónoma de México, Mexico City.

Franke, I., J. Mattos, L. Salinas, C. Mendoza, and S. Zambrano. 2005. Áreas importantes para la conservación de las aves en Perú. Pages 471-510 in BirdLife International and Conservation International. Áreas Importantes para la Conservación de las Aves en Los Andes Tropicales: Sitios Prioritarios para la Conservación de la Biodiversidad. BirdLife International (Serie de Conservación de BirdLife No. 14), Quito, Ecuador.

García-Moreno, J., N. Cortés, G. M. García-Deras, And B. E. HeRnÁNDEZ-BAÑos. 2006. Local origin and diversification among Lampornis hummingbirds: A Mesoamerican taxon. Molecular Phylogenetics and Evolution 38:488-498.

García-Moreno, J., AND J. FJeldSÅ. 2000. Chronology and mode of speciation in the Andean avifauna. Bonner Zoologische Monographien 46:25-46.

García-Moreno, J., A. G. Navarro-Sigüenza, A. T. PeterSON, AND L. A. SÁNCHEZ-GonZÁlEz. 2004. Genetic variation coincides with geographic structure in the Common BushTanager (Chlorospingus ophthalmicus) complex from Mexico. Molecular Phylogenetics and Evolution 33:186-196.

Gilbert, A. 2002. Ramphastidae. Pages 250-287 in Handbook of the Birds of the World, vol. 7: Jacamars to Woodpeckers (J. del Hoyo, A. Elliott, and J. Sargatal, Eds.). Lynx Ediciones, Barcelona, Spain.

Graham, A. 1998. Factores históricos de la diversidad biológica de México. Pages 109-127 in Diversidad Biológica de México: Orígenes y Distribución (T. P. Ramamoorthy, R. Bye, A. Lot, and J. Fa, Eds.). Universidad Nacional Autónoma de México, Mexico City.

Graves, G. R. 1982. Speciation in the Carbonated Flower-Piercer (Diglossa carbonaria) complex of the Andes. Condor 84:114.

HACKetт, S. J. 1996. Molecular phylogenetics and biogeography of tanagers in the genus Ramphocelus (Aves). Molecular Phvlogenetics and Evolution 5:368-382.

HACKetT, S. J., AND C. A. LeHN. 1997. Lack of genetic divergence in a genus (Pteroglossus) of Neotropical birds: The connection between life-history characteristics and levels of genetic divergence. Pages 267-279 in Studies in Neotropical Ornithology Honoring Ted Parker (J. V. Remsen, Jr., Ed.). Ornithological Monographs, no. 48.

Haffer, J. 1967. Speciation in Colombian forest birds west of the Andes. American Museum Novitates 2294:1-57.

Haffer, J. 1974. Avian speciation in tropical South America. Publications of the Nuttall Ornithological Club, no. 14.

Hart L, D. L., AND A. G. Clark. 1997. Principles of Population Genetics, 3rd ed. Sinauer Associates, Sunderland, Massachusetts.

Helbig, A. J., A. G. Knox, D. T. Parkin, G. Sangster, And M. Collinson. 2002. Guidelines for assigning species rank. Ibis 144:518-525.

Hernández-Baños, B. E., A. T. Peterson, A. G. NavarroSigüenza, AND P. Escalante-Pliego. 1995. Bird faunas of the humid montane forests of Mesoamerica: Biogeographic patterns and priorities for conservation. Bird Conservation International 5:251-277.

Hilty, S. L. 2003. Birds of Venezuela. Princeton University Press, Princeton, New Jersey.

Hilty, S. L., AND W. L. Brown. 1986. A Guide to the Birds of Colombia. Princeton University Press, Princeton, New Jersey.

Johnson, K. P., AND M. D. Sorenson. 1999. Phylogeny and biogeography of dabbling ducks (genus: Anas): A comparison of molecular and morphological evidence. Auk 116:792805.

Kattan, G. H., P. Franco, V. Rojas, and G. Morales. 2004. Biological diversification in a complex region: A spatial analysis of faunistic diversity and biogeography of the Andes of Colombia. Journal of Biogeography 31:1829-1839.

LIEBHERR, J. K. 1991. A general area cladogram for montane Mexico based on distributions in the Platynine genera Elliptoleus and Calathus (Coleoptera: Carabidae). Proceedings of Entomological Society of Washington 93:390-406.

Llorente-Bousquets, J. 1983. Sinopsis sistemática y biogeográfica de los Dismorphiinae de México, con especial referencia al género Enantia Huebner (Lepidoptera: Pieridae). Folia Entomológica Mexicana 58:1-207.

Marshall, C. J., AND J. K. Liebherr. 2000. Cladistic biogeography of the Mexican transition zone. Iournal of Biogeography 27:203-216.

MaYr, E. 2000. The biological species concept. Pages 17-29 in Species Concepts and Phylogenetic Theory: A Debate (Q. D. Wheeler, and R. Meier, Eds.). Columbia University Press, New York.

McCarthy, C. 1996-1998. Chromas 1.45. School of Health Science, Griffith University, Gold Coast Campus Southpart, Australia.

MCKitrick, M. C., ANd R. M. Zink. 1988. Species concepts in ornithology. Condor 90:1-14.

Navarro S., A. G., A. T. Peterson, E. López-Medrano, and H. Benítez-Díaz. 2001. Species limits in Mesoamerican Aulacorhynchus toucanets. Wilson Bulletin 113:363-372.

Navarro-Sigüenza, A. G., AND A. T. Peterson. 2004. An alternative species taxonomy of the birds of Mexico. Biota Neotropica 4. [Online.] Available at www.biotaneotropica.org.br/v4n2/ en/fullpaper?bn03504022004+en.

NeI, M. 1987. Molecular Evolutionary Genetics. Columbia University Press, New York.

OMland, K. E., S. M. LANYON, And S. J. Fritz. 1999. A molecular phylogeny of the New World orioles (Icterus): The importance of dense taxon sampling. Molecular Phylogenetics and Evolution 12:224-239.

O'NeIll, J. P., AND A. L. Gardner. 1974. Rediscovery of Aulacorhynchus prasinus dimidiatus (Ridgway). Auk 91:700704.

Pérez-Emán, J. L. 2005. Molecular phylogenetics and biogeography of the Neotropical redstarts (Myioborus; Aves, Parulinae). Molecular Phylogenetics and Evolution 37:511-528.

Peters, J. L. 1948. Check-list of Birds of the World, vol. VI. Harvard University Press, Cambridge, Massachusetts.

Porter, D. M. 1973. The vegetation of Panama: A review. Pages 167-201 in Vegetation and Vegetational History of Northern Latin America (A. Graham, Ed.). Elsevier, New York. 
Posada, D., And K. A. Crandall. 2001. Selecting the best-fit model of nucleotide substitution. Systematic Biology 50:580 601.

Remsen, J. V., JR. 1984. High incidence of "leapfrog" pattern of geographic variation in Andean birds: Implications for the speciation process. Science 224:171-173.

RemSEN, J. V., JR. 2005. Pattern, process, and rigor meet classification. Auk 122:403-413.

Ridgway, R. 1914. The Birds of North and Middle America, part VI. Government Printing Office, Washington, D.C.

Riley, C. M., AND K. G. SMith. 1992. Sexual dimorphism and foraging behavior of Emerald Toucanets Aulacorhynchus prasinus in Costa Rica. Ornis Scandinavica 23:459-466.

Robbins, M. B., T. A. Parker III, and S. E. Allen. 1985. The avifauna of Cerro Pirre, Darién, eastern Panama. Pages 198232 in Neotropical Ornithology (P. A. Buckley, M. S. Foster, E. S. Morton, R. S. Ridgely, and F. G. Buckley, Eds.). Ornithological Monographs, no. 36.

Ronquist, F., AND J. P. Huelsenbeck. 2003. MrBayes 3: Bayesian phylogenetic inference under mixed models. Bioinformatics 19:1572-1574.

Sambrook, J., E. F. Fritsch, And T. Maniatis. 1989. Molecular Cloning: A Laboratory Manual, 2nd ed. Cold Spring Harbor Laboratory Press, Cold Spring Harbor, New York.

Schwartz, P. 1972. On the taxonomic rank on the Yellow-billed Toucanet (Aulacorhynchus calorhynchus). Boletín Sociedad Venezolana de Ciencias Naturales 29:459-476.

Short, L. L., AND J. F. M. Horne. 2001. Toucans, Barbets, and Honeyguides: Ramphastidae, Capitonidae and Indicatoridae. Oxford University Press, Oxford, United Kingdom.

Sibley, C. G., ANd B. L. Monroe, JR. 1990. Distribution and Taxonomy of Birds of the World. Yale University Press, New Haven, Connecticut.

Skutch, A. F. 1967. Life histories of Central American highland birds. Publications of the Nuttall Ornithological Club, no. 7.

Solórzano, S., A. J. BAKER, AND K. OYAma. 2004. Conservation priorities for Resplendent Quetzals based on analysis of mitochondrial DNA control-region sequences. Condor 106:449456.

Sorenson, M. D., J. C. Ast, D. E. Dimcheff, T. Yuri, And D. P. Mindell. 1999. Primers for a PCR-based approach to mitochondrial genome sequencing in birds and other vertebrates. Molecular Phvlogenetics and Evolution 12:105114.

Sullivan, J., E. Arellano, ANd D. S. Rogers. 2000. Comparative phylogeography of Mesoamerican highland rodents: Concerted versus independent response to past climatic fluctuations. American Naturalist 155:755-768.

Sullivan, J., J. A. Markert, And C. W. Kilpatrick. 1997. Phylogeography and molecular systematics of the Peromyscus aztecus species group (Rodentia: Muridae) inferred using parsimony and likelihood. Systematic Biology 46:426-440.

Swofford, D. L. 2000. PAUP*: Phylogenetic Analysis Using Parsimony ("and other methods), version 4.0b4a. Sinauer Associates, Sunderland, Massachusetts.

Thompson, J. D., T. J. Gibson, F. Plewniak, E. Jeanmougin, AND D. G. HigGins. 1997. The CLUSTAL_X windows interface: Flexible strategies for multiple sequence alignment aided by quality analysis tools. Nucleic Acids Research 25:4876-4882.

Toledo, V. M. 1982. Pleistocene changes of vegetation in tropical Mexico. Pages 93-111 in Biological Diversification in the Tropics (G. T. Prance, Ed.). Columbia University Press, New York.

Weckstein, J. D. 2005. Molecular phylogenetics of the Ramphastos toucans: Implications for the evolution of morphology, vocalizations, and coloration. Auk 122:1191-1209.

Wetmore, A. 1968. The Birds of the Republic of Panamá, part 2: Columbidae (Pigeons) to Picidae (Woodpeckers). Smithsonian Miscellaneous Collections, vol. 150. Smithsonian Institution, Washington, D.C.

Whitmore, T. C., and G. T. Prance, Eds. 1987. Biogeography and Quaternary History in Tropical America. Clarendon Press, Oxford, UK.

Wiley, E. O. 1981. Phylogenetics: The Theory and Practice of Phylogenetic Sytematics. Wiley Interscience, New York.

WiNkeR, K. 2000. A new subspecies of toucanet (Aulacorhynchus prasinus) from Veracruz, Mexico. Ornitologia Neotropical 11:253-257.

WRIGHT, S. 1951. The genetical structure of populations. Annals of Eugenics 15:323-354.

WRIGHT, S. 1965. The interpretation of population structure by $F$ statistics with special regard to systems of mating. Evolution 19:395-420.

Associate Editor: K. P. Johnson 